\title{
Patients' Use of Social Media for Diabetes Self-Care: Systematic Review
}

Abdelaziz Elnaggar ${ }^{1}$, MBBS, MPH; Van Ta Park ${ }^{1}$, PhD, MPH; Sei J Lee², MD, MAS; Melinda Bender ${ }^{3}$, PhD, PNP-BC; Lee Anne Siegmund ${ }^{4}$, PhD, RN, ACSM-CEP; Linda G Park ${ }^{1}$, PhD, MS, FNP-BC, FAAN

\footnotetext{
${ }^{1}$ Department of Community Health Systems, School of Nursing, University of California, San Francisco, San Francisco, CA, United States

${ }^{2}$ Division of Geriatrics, School of Medicine, University of California, San Francisco, San Francisco, CA, United States

${ }^{3}$ Department of Family Health Care Nursing, School of Nursing, University of California, San Francisco, San Francisco, CA, United States

${ }^{4}$ Office of Nursing Research and Innovation, Cleveland Clinic, Cleveland, OH, United States
}

\section{Corresponding Author:}

Linda G Park, PhD, MS, FNP-BC, FAAN

Department of Community Health Systems

School of Nursing

University of California, San Francisco

San Francisco, CA

United States

Phone: 14155026616

Email: linda.park@ucsf.edu

\section{Abstract}

Background: Patient engagement with diabetes self-care is critical to reducing morbidity and mortality. Social media is one form of digital health that is available for diabetes self-care, although its use for peer-to-peer communication has not been systematically described, and its potential to support patient self-care is unclear.

Objective: The primary aim of this systematic review was to describe the use of social media among patients (peer-to-peer) to manage diabetes and cardiovascular disease (CVD). The secondary aim was to assess patients' clinical outcomes, behavioral outcomes, quality of life, and self-efficacy resulting from peer-to-peer social media use.

Methods: We conducted a literature search in the following databases: PubMed, EMBASE, Web of Science, CINAHL, and PsycINFO (January 2008 through April 2019). The inclusion criteria were quantitative studies that included peer-to-peer use of social media for self-care of diabetes mellitus (with all subtypes) and CVD, including stroke.

Results: After an initial yield of 3066 citations, we selected 91 articles for a full-text review and identified 7 papers that met our inclusion criteria. Of these, 4 studies focused on type 1 diabetes, 1 study included both type 1 and 2 diabetes, and 2 studies included multiple chronic conditions (eg, CVD, diabetes, depression, etc). Our search did not yield any individual studies on CVD alone. Among the selected papers, 2 studies used commercial platforms (Facebook and I Seek You), 3 studies used discussion forums developed specifically for each study, and 2 surveyed patients through different platforms or blogs. There was significant heterogeneity in the study designs, methodologies, and outcomes applied, but all studies showed favorable results on either primary or secondary outcomes. The quality of studies was highly variable.

Conclusions: The future landscape of social media use for patient self-care is promising. However, current use is nascent. Our extensive search yielded only 7 studies, all of which included diabetes, indicating the most interest and demand for peer-to-peer interaction on diabetes self-care. Future research is needed to establish efficacy and safety in recommending social media use among peers for diabetes self-care and other conditions.

(J Med Internet Res 2020;22(4):e14209) doi: $\underline{10.2196 / 14209}$

\section{KEYWORDS}

social media; diabetes mellitus; peer group; self-care; systematic review 


\section{Introduction}

\section{Background}

Diabetes is one of the most prevalent chronic conditions in the United States and worldwide [1-3], associated with high morbidity and mortality, mainly as a result of complications from cardiovascular disease (CVD) [4-8]. In 2016, the World Health Organization estimated that diabetes was the seventh leading cause of death [9]. Evidence indicates that managing blood glucose and diabetes risk factors (including CVD) can prevent or delay mortality because of CVD by 33\% [10-13]. Patient engagement is critical to successfully managing diabetes and thereby reducing morbidity and mortality $[14,15]$.

Self-care has been described as a vital component in diabetes prevention and management in addition to other chronic conditions such as CVD [16-19]. Defined as a "naturalistic decision - making process addressing both the prevention and management of chronic illness" [16], self-care for chronic disease is a complex, multi-factorial endeavor with few effective intervention strategies to help patients manage their conditions [20]. Patients spend very little time each year with their providers and therefore need to independently build skills, knowledge, and motivation to improve individual outcomes. Several meta-analyses and reviews of multiple self-care intervention trials found lifestyle modification programs were more effective than usual care in improving clinical outcomes for diabetes and CVD [21-23].

Despite the known benefits, patients face many barriers in meeting the necessary lifestyle changes involved in self-care, including depression, poor self-efficacy, and cognitive decline [16]. Given the exponential rise in digital technology use among all age groups in the United States [24], mobile technologies are now frequently employed with lifestyle interventions to promote prevention, management, and self-care of chronic diseases [25-27]. Other technology-based programs such as telehealth and home-based rehabilitation have been successful for older patients and reflect their ability to adapt to the use of technology to support their health [28-30].

Peer-to-peer engagement [31], which is communicating with other people experiencing the same chronic condition to learn more about controlling and managing their condition, was found helpful to overcome some of these barriers [16] and has been shown to facilitate self-care, resulting in improved health behaviors [32]. Peer-to-peer communication through engagement on social media offers a convenient venue that is easily accessible for addressing patients' educational needs and providing real-time interaction with others who share many of the challenges in disease management [33]. In a scoping review of social media use between patients and caregivers, researchers found that social media was used to facilitate self-care in $77.1 \%$ (219/284) studies identified. Among these studies, the majority of conclusions were positive about social media use [34]. Although younger age and ease with technology use have been shown to affect the likelihood of using social media for disease-related support [35], the number of older adults who engage in social media has continued to climb and offers significant potential to affect self-care [24]. In addition, more capable social media users have recognized the potential for providing support to others who are managing chronic conditions [35].

Innovative strategies and effective interventions are required to improve self-care and health outcomes for patients with diabetes and CVD. A recent systematic review found supplementing usual health care services using social media platforms can satisfy patients' social support needs with managing their CVD, which health providers cannot easily accommodate [36]. Therefore, leveraging social media may be a viable strategy to help improve self-care for diabetes. Understanding how patients use social media to manage their chronic disease is a first step in validating social media platforms as a potentially effective intervention strategy to provide peer-to-peer support and improve diabetes self-care.

\section{Study Aims}

The primary aim of this systematic review was to summarize the available evidence on the peer-to-peer use of social media for managing diabetes. A secondary aim was to assess patients' clinical outcomes, behavioral outcomes (ie, self-care and patient activation), quality of life, and self-efficacy resulting from patients' social media use.

\section{Methods}

\section{Overview}

In this systematic review, we conducted a comprehensive search to capture all of the relevant quantitative studies that were published on the use of a social media platform as a communication tool between patients (peer-to-peer) on health-related topics pertaining to diabetes and CVD self-care. The outcome of interest included any change in clinical outcomes, behavioral outcomes, quality of life, and self-efficacy in participating individuals who used social media for peer-to-peer communication. This systematic review was conducted using the Preferred Reporting Items for Systematic Reviews and Meta-Analysis guidelines [37]. The protocol of this review was registered on the International Prospective Register of Systematic Reviews on November 13, 2018, using the same name as this study's review title.

The inclusion criteria included quantitative studies that addressed the use of social media as a communication tool between patients (ie, not between patients and providers). An 11-year interval (January 2008 to April 2019) was used to search for eligible studies as most studies with social media began in the late 2000s [38]. All US and international studies were included if they were available in the English language. We included studies that provided blogs, chats, and discussion forums from their Web-based platforms, but we excluded studies that were solely Web-based interventions (eg, education-based without interactions between participants). We limited our paper to describe the peer-to-peer use of social media and did not include studies describing the effect of health care provider-to-patient interactions on social media. We also excluded articles that did not mention which disease was studied. We excluded studies that were duplicates, book chapters, systematic or meta-analysis reviews, qualitative studies, 
editorials, and meeting abstracts. No studies were excluded on the basis of quality.

A systematic methodology was developed to capture all the relevant data from the selected articles. We ensured our included studies had a clear research question on the basis of population, intervention, comparator, outcomes, and study design criteria (Textbox 1) [39]. This paper presents a narrative synthesis as it was not possible to pool results for a meta-analysis.

Textbox 1. Outline of research questions on the basis of the population, intervention, comparator, outcomes, and study design criteria (PICOS framework).

Population:

- $\quad$ Patients with diabetes

Intervention:

- Use of all social media platforms (eg, discussion forum, blogs, microblogs, and group chatting) for peer-to-peer communication for health-related reasons including support, advice, and education

Comparator:

- Patients receiving the same sort of treatment without social media exposure

- No comparator

Outcome:

- Clinical outcomes (eg, biological measures)

- Behavioral outcomes (eg, self-care and patient activation)

- Quality of life and self-efficacy

Study design:

- Randomized controlled trials

- Cohort

- Cross-sectional

\section{Search Strategy}

The search terms were developed on the basis of our research question with the assistance of a health sciences librarian. The selected terms were intended to capture studies that used the most popular social media platforms in all major languages. These terms were adjusted to fit each database to avoid missing any articles (Multimedia Appendix 1). The literature search was conducted in PubMed, EMBASE, Web of Science (including all the databases included in it), CINAHL, and PsycINFO to identify potential articles. We then conducted a manual review of published articles and their bibliographies to assess eligibility for inclusion. In addition, we conducted a hand search of possible relevant articles in the Journal of Medical Internet Research and JMIR Diabetes.

\section{Study Selection}

Initial screening of the studies was done by 2 independent reviewers (AE and $\mathrm{MB}$ ). Primary screening and data extraction were done using the Cochrane Covidence primary screening and data extraction tool to import all the search results from databases followed by preliminary screening, which included titles and abstracts. If the preliminary screening of the abstract was not conclusive, the full text was screened (AE, MB, and VP). On the basis of the abovementioned criteria, studies were selected for a full-text review, with disagreements resolved by 2 other reviewers (LP and VP) who assessed the eligibility of the studies and approved the final selection of all included studies.

\section{Data Extraction and Analysis}

We developed data extraction guidelines. One reviewer (AE) performed data extraction for each eligible article, which was subsequently verified by a second reviewer (MB). The following variables were extracted from the selected studies: name of the first author, year of publication, country, target condition and age of participants, study design and sample size, exposure or intervention, form of social media and purpose, outcome measures, and results. We conducted a descriptive analysis with a summary of the studies.

\section{Results}

\section{Study Characteristics}

The initial database search applying our terms yielded 3066 citations. After removing duplicates, the remaining 1923 titles and abstracts were screened. On the basis of the inclusion and exclusion criteria, 91 articles were identified as eligible for a full-text review. Of these 91 articles, 84 did not meet the criteria and were eliminated as displayed in Figure 1, leaving 7 studies for inclusion that were related to diabetes and multiple chronic conditions, including CVD. We did not identify any studies focused on CVD alone.

The 7 selected studies for this review included 1 pilot randomized controlled trial (RCT) [40], 1 prospective cohort study [41], 3 cross-sectional studies [42-44], and 2 hybrid cross-sectional/cohort studies $[45,46]$. Of these, 1 study used 
Facebook [46], 1 study used a chat line platform [41], 3 studies used discussion forums that were developed specifically for each study $[40,43,45]$, and 2 studies used surveys to assess the use of social networking sites/blogs $[42,44]$. As presented in Table 1, a total of 2 studies included patients with multiple chronic diseases (including diabetes) and the other 5 studies focused solely on diabetes - 4 studies focused on type 1 diabetes
(T1D) $[40,41,44,46]$, whereas 1 study included both T1D and type 2 diabetes [42]. The other studies included all adults, but some did not specify the mean age of those who participated, as shown in Table 1 . With regard to the country of origin, 3 studies were conducted in the United States, with 4 out of the 7 studies originating from Israel, Macedonia, and Italy. The studies were published between 2011 and 2019.

Figure 1. Flow chart of study selection process.

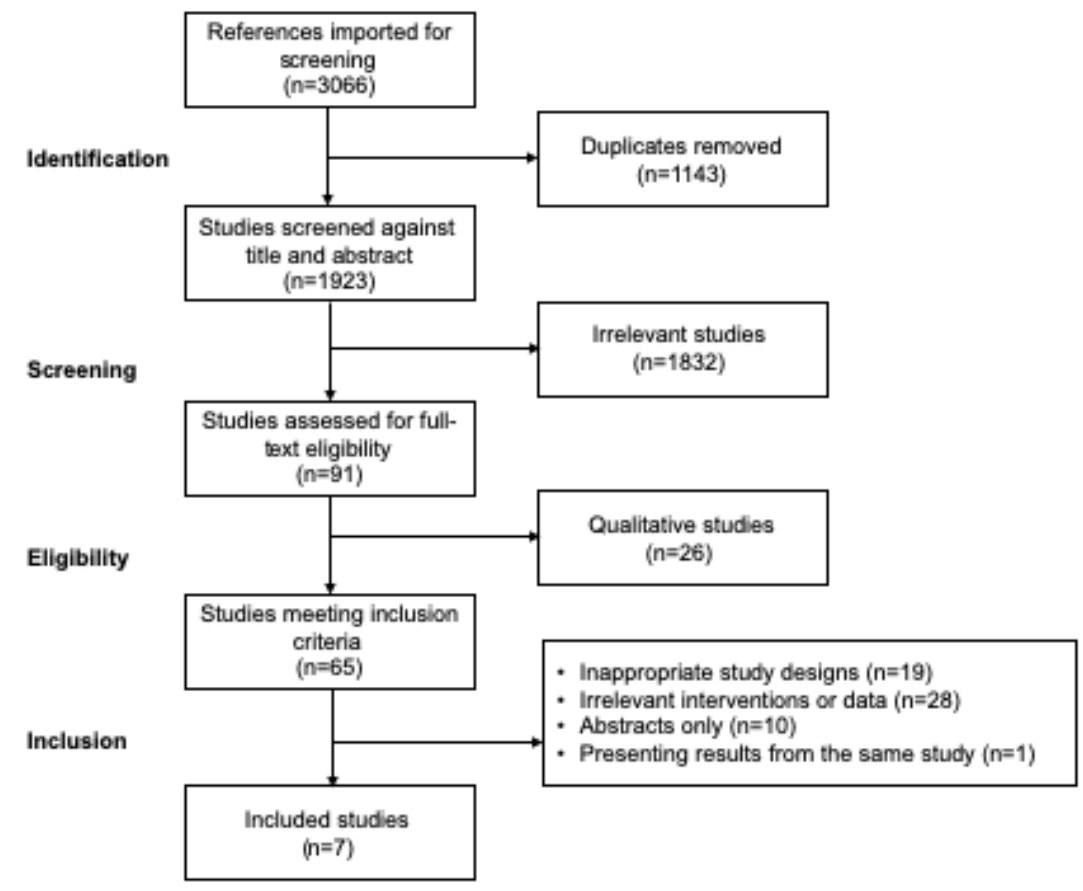


Table 1. Studies on the use of social media among patients for self-care.

\begin{tabular}{|c|c|c|c|c|c|c|}
\hline $\begin{array}{l}\text { References and } \\
\text { country }\end{array}$ & $\begin{array}{l}\text { Target condition and } \\
\text { age group (years) of } \\
\text { participants }\end{array}$ & $\begin{array}{l}\text { Study design } \\
\text { and sample } \\
\text { size }\end{array}$ & $\begin{array}{l}\text { Exposure/intervention } \\
\text { of experimental groups }\end{array}$ & $\begin{array}{l}\text { Form of social } \\
\text { media used } \\
\text { and purpose }\end{array}$ & Outcome measures & Results \\
\hline $\begin{array}{l}\text { Grosberg et al } \\
\text { [45]; Israel }\end{array}$ & $\begin{array}{l}\mathrm{DM}^{\mathrm{a}} \text {, chronic pain, } \\
\text { hypertension, and } \\
\text { depression }(15-\geq 60)\end{array}$ & $\begin{array}{l}\text { Cross-section- } \\
\text { al and } \\
\text { prospective } \\
\text { cohort (3 } \\
\text { months), } \\
\mathrm{N}=686\end{array}$ & $\begin{array}{l}\text { Active participation in } \\
\text { a Hebrew-only website } \\
\text { designed for chronic } \\
\text { conditions }\end{array}$ & $\begin{array}{l}\text { Discussions } \\
\text { and blogs: } \mathrm{Ca} \text { - } \\
\text { moni (a Web- } \\
\text { based social } \\
\text { health net- } \\
\text { work) for ad- } \\
\text { vice, consults } \\
\text { with experts, } \\
\text { and chats with } \\
\text { other patients }\end{array}$ & $\begin{array}{l}\text { Personal Involve- } \\
\text { ment in Health } \\
\text { Care Related to } \\
\text { Site Use, PAM }\end{array}$ & $\begin{array}{l}\text { At baseline, experienced } \\
\text { users had higher PAM } \\
\text { scores (mean 69.3, SD 19.1; } \\
\text { PAM level 4; } P<.001 \text { ) than } \\
\text { new users (mean 62.8, SD } \\
\text { 18.7; PAM level 3). At fol- } \\
\text { low-up, there was a positive } \\
\text { correlation between the fre- } \\
\text { quency of visits or time } \\
\text { spent and } 3 \text { indices of health } \\
\text { empowerment (confidence } \\
\text { from knowledge acquired } \\
\text { about the disease, a sense of } \\
\text { shared support, and personal } \\
\text { involvement in treatment). } \\
\text { PAM scores were higher } \\
\text { among experienced users } \\
\text { compared with new users } \\
\text { (mean } 62.8 \text { vs } 69.3 \text {, respec- } \\
\text { tively; } Z=-4.197 ; P<.001 \text { ) }\end{array}$ \\
\hline $\begin{array}{l}\text { Iafusco et al } \\
\text { [41]; Italy }\end{array}$ & $\begin{array}{l}\mathrm{T}^{\mathrm{c}} \mathrm{D}^{\mathrm{c}}(10-18), \text { mean } \\
\text { age: } 13.6(\mathrm{SD} 2.7) \\
\text { chat group, } 14.1(\mathrm{SD} \\
\text { 2.3) control }\end{array}$ & $\begin{array}{l}\text { Prospective } \\
\text { cohort }(2 \\
\text { years), } \mathrm{N}=396\end{array}$ & $\begin{array}{l}\text { Online group messag- } \\
\text { ing once a week for } 90 \\
\text { min }\end{array}$ & $\begin{array}{l}\text { Group chat- } \\
\text { ting: I Seek } \\
\text { You program } \\
\text { for education- } \\
\text { al purposes } \\
\text { and social sup- } \\
\text { port }\end{array}$ & $\begin{array}{l}\text { DQOLY }{ }^{\mathrm{d}} \text { and } \\
\mathrm{HbA}_{1 \mathrm{c}} \mathrm{e}^{\mathrm{a}}\end{array}$ & $\begin{array}{l}\text { The intervention group } \\
\text { showed significant improve- } \\
\text { ments in all } 3 \text { subscales of } \\
\text { DQOLY compared with the } \\
\text { control: impact of diabetes } \\
\text { (mean } 75, \text { SD } 7 \text { vs mean } 81 \text {, } \\
\text { SD } 14 ; P<.001 \text { ), worries } \\
\text { about diabetes (mean } 27 \text {, SD } \\
3 \text { vs mean } 49 \text {, SD } 2 \text {; } \\
P=.001) \text {, and satisfaction } \\
\text { with life (mean } 68, \text { SD } 13 \\
\text { vs mean } 35, \text { SD } 13 \text {; } \\
P<.001) \text {. No statistically } \\
\text { significant difference } \\
(P=.06) \text { was observed in } \\
\text { HbA } 1 \mathrm{c} \text { values between the } \\
\text { chat and nonchat groups }\end{array}$ \\
\hline $\begin{array}{l}\text { Magnezi et al } \\
\text { [43]; Israel }\end{array}$ & $\begin{array}{l}\mathrm{DM}, \mathrm{CVD}^{\mathrm{f}} \text {, kidney } \\
\text { disease, spinal cord } \\
\text { injury, depres- } \\
\text { sion/anxiety (20- } \\
\geq 65 \text { ) }\end{array}$ & $\begin{array}{l}\text { Cross-section- } \\
\text { al, N=296 }\end{array}$ & $\begin{array}{l}\text { Active participation in } \\
\text { a Hebrew-only website } \\
\text { designed for chronic } \\
\text { conditions }\end{array}$ & $\begin{array}{l}\text { Discussions } \\
\text { and blogs: } \mathrm{Ca} \text { - } \\
\text { moni for ad- } \\
\text { vice, consults } \\
\text { with experts, } \\
\text { and chats with } \\
\text { other patients }\end{array}$ & $\begin{array}{l}\text { Perceived Useful- } \\
\text { ness of Online } \\
\text { Groups, PAM-13 }\end{array}$ & $\begin{array}{l}\text { Perceived usefulness was } \\
\text { significantly higher in the } \\
20-29 \text { age group (mean } 2.26, \\
\text { SD } 1.24 \text { ) than } 50-64 \text { age } \\
\text { group (mean } 1.43, \text { SD } 1.18 \text {; } \\
P=.04 \text { ) and } \geq 65 \text { age group } \\
\text { (mean } 1.38, \text { SD } 1.00 \text {; } \\
P<.05 \text { ). PAM- } 13 \text { was signif- } \\
\text { icantly lower in the } 20-29 \\
\text { age group (mean } 48.44, \text { SD } \\
21.25 \text { ) compared with the } \\
30-39 \text { age group (mean } \\
62.28, \text { SD } 19.78 ; P=.01 \text { ) and } \\
\text { the } 50-64 \text { age group (mean } \\
57.50, \text { SD } 17.66 ; P<.05)\end{array}$ \\
\hline $\begin{array}{l}\text { Nelakurthi et al } \\
\text { [42]; United } \\
\text { States }\end{array}$ & $\begin{array}{l}\text { Type } 1 \text {, type } 2 \text {, and } \\
\text { unspecified type } \\
\text { DM, } \geq 18 \text { (mean age } \\
57, \text { SD 14) }\end{array}$ & $\begin{array}{l}\text { Cross-section- } \\
\text { al, } \mathrm{N}=212\end{array}$ & $\begin{array}{l}\text { Visiting DM-specific } \\
\text { social networking web- } \\
\text { sites }\end{array}$ & $\begin{array}{l}\text { DM-specific } \\
\text { social network- } \\
\text { ing websites }\end{array}$ & $\begin{array}{l}\text { Following advice } \\
\text { regarding eating } \\
\text { habits, exercise } \\
\text { habits, and lifestyle } \\
\text { changes related to } \\
\text { diabetes }\end{array}$ & $\begin{array}{l}\text { Website users showed a sig- } \\
\text { nificant correlation between } \\
\text { offering advice and applying } \\
\text { it to their own eating habits } \\
(r=0.29 ; P=.005) \text {, exercise } \\
(r=0.41 ; P=.001) \text {, and } \\
\text { lifestyle modification } \\
(r=0.38 ; P=.001)\end{array}$ \\
\hline
\end{tabular}




\begin{tabular}{|c|c|c|c|c|c|c|}
\hline $\begin{array}{l}\text { References and } \\
\text { country }\end{array}$ & $\begin{array}{l}\text { Target condition and } \\
\text { age group (years) of } \\
\text { participants }\end{array}$ & $\begin{array}{l}\text { Study design } \\
\text { and sample } \\
\text { size }\end{array}$ & $\begin{array}{l}\text { Exposure/intervention } \\
\text { of experimental groups }\end{array}$ & $\begin{array}{l}\text { Form of social } \\
\text { media used } \\
\text { and purpose }\end{array}$ & Outcome measures & Results \\
\hline
\end{tabular}

Petrovski et al
[46]; Macedonia

\section{T1D (11-25), mean} age: noninternet group 15.2 (SD 2.9), internet group 16.4 (SD 1.9) al and retrospective cohort, $\mathrm{N}=728$ in a national closed Facebook group
Discussion and blogs: Facebook, better blood glucose control, and social support
$\mathrm{HbA}_{1 \mathrm{c}}(\%), \mathrm{HbA}_{1 \mathrm{c}}$ (mmol/mol), diabetes ketoacidosis per patient/year, severe hypoglycemia per patient/year, and total daily insulin

Cross-section- Only passive readers of T1D-related $\quad \mathrm{HbA}_{1 \mathrm{c}}(\%)$

Oser et al [44]; T1D $(\geq 18)$ United States al, $\mathrm{N}=282$ T1D-related blogs with blogs no active contribution, insulin pump use, and $\mathrm{CGM}^{\mathrm{h}}$
Significant differences in the Facebook group between $\mathrm{HbA}_{1 \mathrm{c}}(\%)$ and $\mathrm{HbA}_{1 \mathrm{c}}$ (mmol/mol; mean 7.1, SD 3.2 and mean 54, SD 35, respectively) compared with the control (mean 7.6, SD 2.8 and mean 60 , SD 31, respectively; $P<.05$ in both). No significant differences in other measures

$\mathrm{HbA}_{1 \mathrm{c}}$ levels of blog users were significantly lower than nonusers $(7.0 \%$ vs $7.5 \% ; P=.006)$, blog readers on insulin pump vs blog nonusers and those not on insulin pump $(7.0 \%$ vs $8.0 \%)$, and blog users using CGM vs blog nonusers not using CGM (6.9\% vs $7.5 \%)$

\footnotetext{
${ }^{\mathrm{a}} \mathrm{DM}$ : diabetes mellitus.

${ }^{b}$ PAM: Patient Activation Measure.

${ }^{\mathrm{C}}$ T1D: type 1 diabetes.

d DQOLY: Diabetes Quality of Life for Youth Inventory.

${ }^{\mathrm{e}} \mathrm{HbA}_{1 \mathrm{c}}$ : glycated hemoglobin.

${ }^{\mathrm{f}} \mathrm{CVD}$ :cardiovascular disease

$\mathrm{g}_{\mathrm{RCT}}$ : randomized controlled trial.

${ }^{\mathrm{h}} \mathrm{CGM}$ : continuous glucose monitor.
}

\section{Form of Social Media Used and Purpose}

Out of the 7 studies, 4 used discussion forums or blogs, either through websites developed especially for the targeted population [40,43-45] or through commercially available platforms (eg, Facebook and I Seek You) [41,46]; 2 studies did not use a platform or website but instead evaluated respondents' social networking site behaviors [42,44]; 2 studies used social media as a form of social support $[40,46] ; 3$ studies assessed the usefulness of the platforms for educational purposes $[41,43,45] ; 2$ studies used social media as a tool to improve blood sugar control through educating participants on the technicalities of blood glucose measurement and management, especially for the youth [40,46]; and 1 study assessed the accessibility and usefulness of Web-based medical information [42].

\section{A Description of Social Media Use and Intended Outcomes}

\section{Clinical Outcomes}

Concerning clinical outcomes, 3 of the 7 studies reviewed reported glycated hemoglobin $\left(\mathrm{HbA}_{1 \mathrm{c}}\right)$. Petrovski and Zivkovic [46] and Iafusco et al [41] focused on the adolescent age group, whereas Oser et al [44] targeted adults ( $\geq 18$ years) with T1D. Petrovski and Zivkovic [46] sought to evaluate a Facebook group as a communication tool to interact with questions, answers, and comments to improve glucose control among adolescents and young people with T1D. Using a retrospective cohort design, Petrovski and Zivkovic [46] reported on data that were collected about Facebook users via electronic medical records and a cross-sectional analysis via social media (both 
Facebook and Viber). Patients from the Facebook group had a mean of 1.5 (SD 3.5) posts per day [46]. Among 728 members in their diabetes center, they found significantly lower levels of $\mathrm{HbA}_{1 \mathrm{c}}$ among Facebook group users compared with nonusers 1 year after joining the closed Facebook group (users mean 7.1, SD 3.2; nonusers mean 7.6, SD 2.8; $P<.05 ; \mathrm{N}=728$ ) [46].

Iafusco et al [41] evaluated the effectiveness of a chat line for T1D education among the youth using a prospective cohort design. In contrast to the study above, Iafusco et al [41] did not find a statistically significant difference in $\mathrm{HbA}_{1 \mathrm{c}}$ levels between 2 groups after adjusting for therapy choice, although the differences approached significance $(P=.05)$. $\mathrm{HbA}_{1 \mathrm{c}}$ was assessed on each participant $(\mathrm{N}=396)$ at baseline, year 1 , and year $2(\mathrm{~N}=193)$ [41]. One important consideration of this study is that children mature physically, mentally, and emotionally over the course of 2 years. It is possible that $\mathrm{HbA}_{1 \mathrm{c}}$ changed similarly for both groups because blood glucose control was an issue of maturity and not necessarily related to the chat line.

Oser et al [44] focused on adults with T1D to assess $\mathrm{HbA}_{1 \mathrm{c}}$ differences between blog readers and blog nonusers [44]. This cross-sectional study also looked at differences in technology use (insulin pump and continuous glucose monitors) in these 2 groups and self-reported $\mathrm{HbA}_{1 \mathrm{c}}$ differences in blog use and technology subgroups [44]. Among 214 blog readers and 68 blog nonusers who completed their survey, the authors found $\mathrm{HbA}_{1 \mathrm{c}}$ was lower for blog readers $(7.0 \%)$ compared with blog nonusers $(7.5 \% ; P=.006)$ [44]. The difference between blog users vs blog nonusers was compared with the clinically significant difference in $\mathrm{HbA}_{1 \mathrm{c}}$ seen among those who used continuous glucose monitors (compared with nonusers) and insulin pump use (compared with multiple daily injections) [44]. These results show that reading and communicating through blogs with other individuals with diabetes leads to learning pertinent information and thereby is associated with lower $\mathrm{HbA}_{1 \mathrm{c}}$ values [44].

\section{Behavioral Outcomes}

Magnezi et al [43] and Grosberg et al [45], in 2 separate studies, evaluated patient activation (defined as a patient's level of active participation in his or her health care) with chronic care management as a result of using social media. In particular, they examined the use of an online health-related social network called Camoni, a platform that was developed for individuals with a variety of chronic diseases to assist them in finding others with similar conditions $[43,45]$. The website provided advice about their common condition through blogs, discussion forums, online support groups, chats, and a secure channel to communicate with experts. Magnezi et al [43] included individuals with 5 chronic conditions: diabetes mellitus, CVD, renal disease, and depression/anxiety $(\mathrm{N}=296)$, whereas Grosberg et al [45] focused on individuals with diabetes, chronic pain, hypertension, and depression $(\mathrm{N}=696)$. The purpose of the studies was to evaluate the effects and benefits of participating in an online health-related social network on patient activation and to determine which variables predict the perceived usefulness of the site $[43,45]$. They found that the usefulness of the website was negatively correlated with age, and it was perceived as being more useful among participants who were less involved in their own care [43]. In addition, the level of activity on the website correlated with the perceived usefulness [43], and those with at least six months experience on the site had the highest patient activation scores (level 4) compared with new visitors $(P<.001)$ [45]. There was a significant positive association among experienced users between both the frequency and duration of website visits and self-reported personal empowerment in health [45]. Gender differences were documented as men browsed the website for more than $30 \mathrm{~min}$, whereas the average time for women was 10 to $30 \mathrm{~min}$ [45].

Using a cross-sectional study design, 2 separate studies conducted by Nelakurthi and colleagues [42] and Iafusco and colleagues [41] sought to evaluate the reasons behind the use of social networking sites among patients with diabetes and its impact on self-care. Nelakurthi et al [42] used surveys distributed through clinics and websites, whereas Iafusco et al [41] used a chat line moderated by a supervised physician, although it was unclear in the paper by Nelakurthi et al [42] which clinics and health websites were used and accessed by the patients. The top 2 reported reasons for the use of social networking sites were either to offer support or to share personal experiences [42]. Self-reported insulin therapy was significantly higher among users of social media $(P=.01)$ [42]. Respondents were more likely to follow the advice received from the website about lifestyle changes and diabetes care compared with advice that was received from their health care provider, $69 \%$ and $65 \%$ of the time, respectively [42]. However, Iafusco et al [41] revealed that most of the patients thought that sharing $\mathrm{HbA}_{1 \mathrm{c}}$ readings on the group page was motivational for the other members of the group (64\%) with the use of both Facebook and Viber.

\section{Quality of Life and Self-Efficacy Factors}

We found 2 other themes among 2 of the studies in this review: self-efficacy and quality of life. In a pilot RCT, Newton and Ashley [40] recruited adolescents (13-18 years of age) with T1D to assess the efficacy of a website, DiabetesTeenTalk.com, which provided blogs, chat rooms, and discussion forums to improve adherence to treatment protocols. All of the components were designed using Bandura's self-efficacy theory [47]. Although 81 participants were recruited, 59 completed the pretests, and $50(85 \%)$ completed the posttests at 7 weeks [40]. In addition to standard medical care, the experimental group participated in the intervention through logging into the website at least three times weekly over 7 weeks, updated their blogs, and participated in the discussion forums and chats; the control group received standard medical care only [40]. Blinding of subjects was not feasible considering the intervention. However, the assessors of outcomes were not blinded. Differences in characteristics between experimental and control patients were not compared with statistical analyses, although there appeared to be differences in age groups and gender between the intervention and control groups.

Newton and Ashley [40] assessed the effectiveness of the intervention using Diabetes Quality of Life for Youths (DQOLY), Self-Efficacy of Diabetes Self-Management, and Outcome Expectations of Diabetes Self-Management. 
Comparatively, Iafusco et al [41] examined DQOLY ( $\mathrm{N}=396)$ at baseline, year 1, and year $2(\mathrm{~N}=193)$. Newton and Ashley [40] found no significant differences between treatment groups on quality of life scores $(P=.63)$, self-efficacy scores $(P=.53)$, or negative outcome expectations $(P=.31)$. However, the control group had higher positive outcome expectations (mean 48.1, SD 6.3) than those in the experimental group (mean 44.5, SD $6.9 ; P=.03)$ [40]. A large majority $(78 \%)$ of the participants in the intervention group indicated that social support was the most helpful component of the website [40]. Iafusco et al [41] identified significant positive improvements in all subscales of DQOLY in the intervention (chat) group compared with controls who were randomly selected because they refused to participate in chat sessions [41]. At year 2, these included impact of diabetes (chat: mean 75, SD 7; nonchat: mean 81, SD 14; $P<.001$ ), worries about diabetes (chat: mean 27, SD 3; nonchat: mean 49, SD 2; $P=.001$ ), and satisfaction with life (chat: mean 68, SD 3; nonchat: mean 35, SD 13; $P<.001$ ) [41].

\section{Discussion}

\section{Principal Findings}

To our knowledge, this paper is the first to systematically review the literature for quantitative studies on the use of social media by patients with diabetes to communicate with peers for self-care. We identified 7 studies that examined the use of social media in managing various types of diabetes and reported on participants' change in clinical outcomes, behavioral outcomes, quality of life, and self-efficacy factors as the study outcomes. The studies were diverse, utilizing various social media platforms (eg, discussion forums, blogs, and group chats), research designs and methodologies (eg, RCT, feasibility, prospective and retrospective cohort, and cross-sectional), outcomes (eg, questionnaires and clinical/laboratory measures), and patient populations (eg, adolescents, young adults). Although there is no consensus among experts on the best form of social media platform to connect patients with each other, there is a promising benefit of using Facebook groups, blogs, and mobile phone apps for connecting patients with chronic conditions to their peers.

Both commercially available and customized social media platforms were used by patients in our review. Facebook groups have been found to be a useful tool as they provide a multimodal platform to access content, deliver skills, monitor progress, and organize online and live groups [48,49]. In addition, these groups could be a useful tool for patients and their caregivers to learn about blood glucose devices and receive technological assistance. Through closed private groups, members provided assistance to the community by spreading awareness, technical assistance, and emotional support. Furthermore, members put a high level of trust in their peers and followed their advice in many health situations about lifestyle changes for their chronic conditions, although almost all patients reported no harm using Facebook [46,50]. Similarly, establishing online connections with other individuals experiencing a similar chronic condition through blogging was shown to decrease the sense of isolation and increase the sense of purpose. In addition, active engagement in blogs was shown to be associated with a higher sense of self-accountability and provided a greater opportunity for patients to gain knowledge about their conditions [51,52].

Among the studies we included in this review, users' interactions with one another in the platforms were structured by 4 elements: (1) seeking support or encouragement from individuals with similar conditions, (2) seeking information and advice about clinical diabetes care, (3) obtaining advice about lifestyle changes, and (4) providing a sense of companionship [42,53]. Although obtaining information was the primary motive behind using these platforms rather than seeking relationships, several studies demonstrated that social support and motivation were the most helpful components of these platforms. For instance, a few studies demonstrated that most of the patients shared their last $\mathrm{HbA}_{1 \mathrm{c}}$ level with a social media group, which was used as a motivational and supportive tool for other patients $[40,42,46]$. Similarly, some were motivated to make other contributions in various forms, such as informational, technical, emotional, or financial support [51].

Our findings are consistent with a recent scoping review by Litchman et al [54] who assessed the potential or actual benefits and consequences of using a diabetes online community (DOC) by analyzing different study designs (cohort, cross-sectional, social network analysis, and text mining). They found that DOC use was highly beneficial with minimal risk or negative consequences [54]. Our review updates this earlier review, which analyzed patients' communication with each other by focusing on quantitative studies. In addition, unlike our study that focused on peer-to-peer interactions, previous reviews have reported on studies between patients and health care providers and showed positive outcomes with using social media and improvement in patient care to provide social, emotional, or experiential support in chronic diseases $[48,49]$.

\section{Potential Impact of Social Media in Diabetes}

The benefit of peer-to-peer use is that social ties formed on online platforms provide support for self-care activities that can improve an individual's perceived illness experience, a particularly difficult area to address otherwise [55-60]. Social media platforms provide social support with practical options for facilitating self-care and emotional support to those living with chronic conditions [61-63], which is preferred by patients except when information on prescription medications is needed. In addition, there is no liability to the health care provider with peer-to-peer communication. Health care providers need to assess their capacity to monitor and any potential risks before encouraging widespread use of social media as a communication tool for patients and families [46] and include the communication as a part of the patient's health record. The American Association of Diabetes Educators emphasized in their most recent guidelines about the various benefits of online peer support, which included clinical, behavioral, psychosocial, and educational support [64]. This adds to the potential benefit of incorporating social media use for the management of chronic conditions such as diabetes mellitus.

\section{Consideration of Potential Risks}

Accuracy and creditability of medical information obtained from social media platforms remains to be one of the primary 
concerns to patients. A number of studies have found that DOCs have beneficial effects with minimal risk [50,65-67]. Although there were positive results in this review with social media use overall, one should consider the risks that may emerge from using these platforms. These risks include access to misinformation, difficulty interpreting medical or scientific outcomes for the average reader, threats to individuals' privacy, and distraction by advertisements on the blogs [57,67-69]. There are limited data on the potential negative outcomes resulting from such activities to warn against using social media with chronic conditions. In addition, there are currently no rigorous quantitative or qualitative data to support the use of social media within the domains of diagnosis or education.

\section{Limitations}

There are limitations to be considered in our study. A systematic approach was used to select the relevant articles in the literature; however, we were unable to assess the methodological quality across studies because of the various study designs and some studies using a hybrid approach of cross-sectional surveys with cohort studies. A noted limitation is the small number of studies that fit the inclusion criteria of peer-to-peer communication for this systematic review paper. However, this strengthens the argument that many more clinical research opportunities exist in this area. In addition, because an inclusion criterion for this review paper included the specific mention of a chronic condition (ie, CVD, stroke, or diabetes), it is plausible that there may have been papers that were inadvertently excluded that did include these chronic conditions. Although some of the studies did not include a mean age, the majority of participants were adolescents or young adults, thus our conclusions cannot be generalized to older populations. Finally, this review only included studies published in the English language. Therefore, it is possible some relevant studies may have been excluded.

\section{Future Research}

Future research opportunities and current gaps have been identified in this review. There is a clear need to conduct more rigorous RCTs on patients using social media to manage their chronic disease through peer-to-peer communication as we only identified 1 pilot study. By providing a strong evidence base for applying social media for self-care, we will be able to determine the efficacy of using these platforms. We must also improve our outreach to diverse populations (ie, age, types of chronic disease, and race/ethnicity) and geographic locations to establish generalizability. Social media interventions need to be tested with the overall goal of engaging patients, caregivers, and providers to improve health and psychosocial outcomes. Given the limited studies that were included in this systematic review paper, some questions require future research: What type of social media platforms are the most effective and feasible? Which is better in the self-care of chronic conditions: commercially available or customized social media platforms? Which populations benefit the most from the use of social media for the self-care of chronic conditions?

\section{Conclusions}

This review contributes to our limited understanding of the impact of using contemporary social media platforms as a peer-to-peer communication tool among patients with diabetes to enhance self-care. Findings from this review may serve as a resource for researchers and clinicians to tailor their interventions in the way social media is currently used between patients and/or diversify their social media platforms according to the communities that they serve. There is a paucity of published research on social media use for peer-to-peer communication among patients with diabetes, which provides a ripe opportunity for clinicians and scientists to explore this digital means of communication among patients with chronic diseases. Social media platforms provide a cost-effective tool that may improve patient self-care and knowledge [54], thereby increasing patient activation, improving problem solving, and providing social support.

\section{Acknowledgments}

The authors would like to thank Julia von Oppenfeld, BA, for her editorial assistance with this manuscript. Also, Evans Whitaker, MD, MLIS, for his help developing the search terms.

\section{Conflicts of Interest}

None declared.

\section{Multimedia Appendix 1}

The search terms used to generate this review.

[DOCX File, 15 KB-Multimedia Appendix 1]

\section{References}

1. Centers for Disease Control and Prevention (CDC). 2017. National Diabetes Statistics Report, 2017 URL: https://www. cdc.gov/diabetes/pdfs/data/statistics/national-diabetes-statistics-report.pdf [accessed 2020-02-14]

2. Yach D, Leeder SR, Bell J, Kistnasamy B. Global chronic diseases. Science 2005 Jan 21;307(5708):317. [doi: 10.1126/science.307.5708.317] [Medline: $\underline{15661976}$ ] 
3. Joszt L. The American Journal of Managed Care. 2017 Nov 28. Identifying the Most Prevalent and Costly Chronic Conditions in Medicaid URL: https://www.ajmc.com/newsroom/identifying-the-most-prevalent-and-costly-chronic-conditionsin-medicaid [accessed 2020-02-14]

4. Szuszkiewicz-Garcia MM, Davidson JA. Cardiovascular disease in diabetes mellitus: risk factors and medical therapy. Endocrinol Metab Clin North Am 2014 Mar;43(1):25-40. [doi: 10.1016/j.ecl.2013.09.001] [Medline: 24582090]

5. Yu OH, Suissa S. Identifying causes for excess mortality in patients with diabetes: closer but not there yet. Diabetes Care 2016 Nov;39(11):1851-1853. [doi: 10.2337/dci16-0026] [Medline: 27926885]

6. Bertoni AG, Krop JS, Anderson GF, Brancati FL. Diabetes-related morbidity and mortality in a national sample of US elders. Diabetes Care 2002 Mar;25(3):471-475. [doi: 10.2337/diacare.25.3.471] [Medline: 11874932]

7. Zhou C, Byard RW. An analysis of the morbidity and mortality of diabetes mellitus in a forensic context. J Forensic Sci 2018 Jul;63(4):1149-1154. [doi: 10.1111/1556-4029.13674] [Medline: 29228513]

8. Emerging Risk Factors Collaboration, Sarwar N, Gao P, Seshasai SR, Gobin R, Kaptoge S, et al. Diabetes mellitus, fasting blood glucose concentration, and risk of vascular disease: a collaborative meta-analysis of 102 prospective studies. Lancet 2010 Jun 26;375(9733):2215-2222 [FREE Full text] [doi: 10.1016/S0140-6736(10)60484-9] [Medline: 20609967]

9. World Health Organization. 2018 Oct 30. Diabetes URL: https://www.who.int/news-room/fact-sheets/detail/diabetes [accessed 2003-10-19]

10. Kottke TE, Faith DA, Jordan CO, Pronk NP, Thomas RJ, Capewell S. The comparative effectiveness of heart disease prevention and treatment strategies. Am J Prev Med 2009 Jan;36(1):82-88. [doi: 10.1016/j.amepre.2008.09.010] [Medline: 19095166]

11. Fonseca VA. Defining and characterizing the progression of type 2 diabetes. Diabetes Care 2009 Nov;32(Suppl 2):S151-S156 [FREE Full text] [doi: $10.2337 /$ dc09-S301] [Medline: 19875543 ]

12. Nesmith JD. Type 2 diabetes mellitus in children and adolescents. Pediatr Rev 2001 May;22(5):147-152. [doi: 10.1542/pir.22-5-147] [Medline: 11331736]

13. DeFronzo RA. Current issues in the treatment of type 2 diabetes. Overview of newer agents: where treatment is going. Am J Med 2010 Mar;123(3 Suppl):S38-S48. [doi: 10.1016/j.amjmed.2009.12.008] [Medline: 20206731]

14. Peters AE, Keeley EC. Patient engagement following acute myocardial infarction and its influence on outcomes. Am J Cardiol 2017 Nov 1;120(9):1467-1471. [doi: 10.1016/j.amjcard.2017.07.037] [Medline: 28843395]

15. Sacks R, Greene J, Hibbard J, Overton V, Parrotta C. Does patient activation predict the course of type 2 diabetes? A longitudinal study. Patient Educ Couns 2017 Jul;100(7):1268-1275. [doi: 10.1016/j.pec.2017.01.014] [Medline: 28159442]

16. Riegel B, Moser DK, Buck HG, Dickson VV, Dunbar SB, Lee CS, American Heart Association Council on Cardiovascular and Stroke Nursing; Council on Peripheral Vascular Disease;Council on Quality of Care and Outcomes Research. Self-care for the prevention and management of cardiovascular disease and stroke: a scientific statement for healthcare professionals from The American Heart Association. J Am Heart Assoc 2017 Aug 31;6(9):pii: e006997 [FREE Full text] [doi: 10.1161/JAHA.117.006997] [Medline: 28860232]

17. Beck J, Greenwood DA, Blanton L, Bollinger ST, Butcher MK, Condon JE, 2017 Standards Revision Task Force. 2017 National standards for diabetes self-management education and support. Diabetes Care 2017 Oct;40(10):1409-1419. [doi: 10.2337/dci17-0025] [Medline: 28754780]

18. White N, Manning ML, Brawer R, Plumb J. Using accreditation standards as a framework to evaluate and improve a community-based diabetes self-management education program. Popul Health Manag 2014 Feb;17(1):8-12. [doi: 10.1089/pop.2013.0044] [Medline: 24138340]

19. Wahowiak L. Providing lifelong education and support: updates in the 2017 National Standards for Diabetes Self-Management Education and Support. Diabetes Spectr 2017 Nov;30(4):298-300 [FREE Full text] [doi: 10.2337/ds17-0060] [Medline: 29151720]

20. Grady PA, Gough LL. Self-management: a comprehensive approach to management of chronic conditions. Am J Public Health 2014 Aug;104(8):e25-e31. [doi: 10.2105/AJPH.2014.302041] [Medline: 24922170]

21. Janssen V, de Gucht V, Dusseldorp E, Maes S. Lifestyle modification programmes for patients with coronary heart disease: a systematic review and meta-analysis of randomized controlled trials. Eur J Prev Cardiol 2013 Aug;20(4):620-640. [doi: 10.1177/2047487312462824] [Medline: 23022703]

22. Cardona-Morrell M, Rychetnik L, Morrell SL, Espinel PT, Bauman A. Reduction of diabetes risk in routine clinical practice: are physical activity and nutrition interventions feasible and are the outcomes from reference trials replicable? A systematic review and meta-analysis. BMC Public Health 2010 Oct 29;10:653 [FREE Full text] [doi: 10.1186/1471-2458-10-653] [Medline: 21029469]

23. Alharbi M, Gallagher R, Kirkness A, Sibbritt D, Tofler G. Long-term outcomes from Healthy Eating and Exercise Lifestyle Program for overweight people with heart disease and diabetes. Eur J Cardiovasc Nurs 2016 Feb;15(1):91-99. [doi: 10.1177/1474515114557222] [Medline: 25344059]

24. Pew Research Center. 2019 Jun 12. Mobile Fact Sheet URL: https://www.pewresearch.org/internet/fact-sheet/mobile/ [accessed 2019-07-01] 
25. Santarossa S, Kane D, Senn CY, Woodruff SJ. Exploring the role of in-person components for online health behavior change interventions: can a digital person-to-person component suffice? J Med Internet Res 2018 Apr 11;20(4):e144 [FREE Full text] [doi: 10.2196/jmir.8480] [Medline: 29643048]

26. Whittaker R, McRobbie H, Bullen C, Rodgers A, Gu Y. Mobile phone-based interventions for smoking cessation. Cochrane Database Syst Rev 2016 Apr 10;4:CD006611 [FREE Full text] [doi: 10.1002/14651858.CD006611.pub4] [Medline: 27060875]

27. Cui M, Wu X, Mao J, Wang X, Nie M. T2DM self-management via smartphone applications: a systematic review and meta-analysis. PLoS One 2016;11(11):e0166718 [FREE Full text] [doi: 10.1371/journal.pone.0166718] [Medline: 27861583]

28. Bernocchi P, Vitacca M, La Rovere MT, Volterrani M, Galli T, Baratti D, et al. Home-based telerehabilitation in older patients with chronic obstructive pulmonary disease and heart failure: a randomised controlled trial. Age Ageing 2018 Jan 1;47(1):82-88. [doi: 10.1093/ageing/afx146] [Medline: 28985325]

29. Inglis SC, Conway A, Cleland JG, Clark RA. Is age a factor in the success or failure of remote monitoring in heart failure? Telemonitoring and structured telephone support in elderly heart failure patients. Eur J Cardiovasc Nurs 2015 Jun;14(3):248-255. [doi: 10.1177/1474515114530611] [Medline: 24681423]

30. Wolkanin-Bartnik J, Pogorzelska H, Bartnik A. Patient education and quality of home-based rehabilitation in patients older than 60 years after acute myocardial infarction. J Cardiopulm Rehabil Prev 2011;31(4):249-253. [doi:

10.1097/HCR.0b013e31821c1391] [Medline: 21623216]

31. Lauckner H, Hutchinson SL. Peer support for people with chronic conditions in rural areas: a scoping review. Rural Remote Health 2016;16(1):3601 [FREE Full text] [Medline: 26943760]

32. Fisher EB, Boothroyd RI, Elstad EA, Hays L, Henes A, Maslow GR, et al. Peer support of complex health behaviors in prevention and disease management with special reference to diabetes: systematic reviews. Clin Diabetes Endocrinol 2017;3:4 [FREE Full text] [doi: 10.1186/s40842-017-0042-3] [Medline: 28702258]

33. Roblin DW. The potential of cellular technology to mediate social networks for support of chronic disease self-management. J Health Commun 2011;16(Suppl 1):59-76. [doi: 10.1080/10810730.2011.596610] [Medline: 21843096]

34. Hamm MP, Chisholm A, Shulhan J, Milne A, Scott SD, Given LM, et al. Social media use among patients and caregivers: a scoping review. BMJ Open 2013 May 9;3(5):pii: e002819 [FREE Full text] [doi: 10.1136/bmjopen-2013-002819] [Medline: 23667163]

35. Partridge SR, Grunseit AC, Gallagher P, Freeman B, O'Hara BJ, Neubeck L, et al. Cardiac patients' experiences and perceptions of social media: mixed-methods study. J Med Internet Res 2017 Sep 15;19(9):e323 [FREE Full text] [doi: 10.2196/jmir.8081] [Medline: 28916507]

36. Smailhodzic E, Hooijsma W, Boonstra A, Langley DJ. Social media use in healthcare: a systematic review of effects on patients and on their relationship with healthcare professionals. BMC Health Serv Res 2016 Aug 26;16:442 [ㅍREE Full text] [doi: 10.1186/s12913-016-1691-0] [Medline: 27562728]

37. Moher D, Liberati A, Tetzlaff J, Altman DG, PRISMA Group. Preferred reporting items for systematic reviews and meta-analyses: the PRISMA statement. Br Med J 2009 Jul 21;339:b2535 [FREE Full text] [doi: 10.1136/bmj.b2535] [Medline: 19622551]

38. Giustini D, Ali SM, Fraser M, Kamel Boulos MN. Effective uses of social media in public health and medicine: a systematic review of systematic reviews. Online J Public Health Inform 2018;10(2):e215 [FREE Full text] [doi: 10.5210/ojphi.v10i2.8270] [Medline: $\underline{\text { 30349633] }}$

39. Higgins J, Green S. Cochrane Training. 2011 Mar. Cochrane Handbook for Systematic Reviews of Interventions Version 5.1.0 URL: https://training.cochrane.org/handbook/archive/v5.1/ [accessed 2003-02-19]

40. Newton KT, Ashley A. Pilot study of a web-based intervention for adolescents with type 1 diabetes. J Telemed Telecare 2013 Dec;19(8):443-449. [doi: 10.1177/1357633X13512069] [Medline: 24197399]

41. Iafusco D, Galderisi A, Nocerino I, Cocca A, Zuccotti G, Prisco F, et al. Chat line for adolescents with type 1 diabetes: a useful tool to improve coping with diabetes: a 2-year follow-up study. Diabetes Technol Ther 2011 May;13(5):551-555. [doi: 10.1089/dia.2010.0188] [Medline: 21406010]

42. Nelakurthi AR, Pinto AM, Cook CB, Jones L, Boyle M, Ye J, et al. Should patients with diabetes be encouraged to integrate social media into their care plan? Future Sci OA 2018 Jul;4(7):FSO323 [FREE Full text] [doi: 10.4155/fsoa-2018-0021] [Medline: 30112191]

43. Magnezi R, Bergman YS, Grosberg D. Online activity and participation in treatment affects the perceived efficacy of social health networks among patients with chronic illness. J Med Internet Res 2014 Jan 10;16(1):e12 [FREE Full text] [doi: 10.2196/jmir.2630] [Medline: 24413148]

44. Oser SM, Stuckey HL, Parascando JA, McGinley EL, Berg A, Oser TK. Glycated hemoglobin differences among blog-reading adults with type 1 diabetes compared with those who do not read blogs: cross-sectional study. JMIR Diabetes 2019 Apr 2;4(2):e13634 [FREE Full text] [doi: 10.2196/13634] [Medline: 30938693]

45. Grosberg D, Grinvald H, Reuveni H, Magnezi R. Frequent surfing on social health networks is associated with increased knowledge and patient health activation. J Med Internet Res 2016 Aug 10;18(8):e212 [FREE Full text] [doi:

10.2196/jmir.5832] [Medline: 27511272] 
46. Petrovski G, Zivkovic M. Are we ready to treat our diabetes patients using social media? Yes, we are. J Diabetes Sci Technol 2019 Mar;13(2):171-175 [FREE Full text] [doi: 10.1177/1932296818795441] [Medline: $\underline{\text { 30132685] }}$

47. Bandura A. Self-efficacy: toward a unifying theory of behavioral change. Psychol Rev 1977 Mar;84(2):191-215. [doi: 10.1037//0033-295x.84.2.191] [Medline: 847061]

48. Patel R, Chang T, Greysen SR, Chopra V. Social media use in chronic disease: a systematic review and novel taxonomy. Am J Med 2015 Dec;128(12):1335-1350. [doi: 10.1016/j.amjmed.2015.06.015] [Medline: 26159633]

49. Merolli M, Gray K, Martin-Sanchez F. Health outcomes and related effects of using social media in chronic disease management: a literature review and analysis of affordances. J Biomed Inform 2013 Dec;46(6):957-969 [FREE Full text] [doi: 10.1016/j.jbi.2013.04.010] [Medline: 23702104]

50. White K, Gebremariam A, Lewis D, Nordgren W, Wedding J, Pasek J, et al. Motivations for participation in an online social media community for diabetes. J Diabetes Sci Technol 2018 May;12(3):712-718 [FREE Full text] [doi: 10.1177/1932296817749611] [Medline: 29310448]

51. Vaala SE, Lee JM, Hood KK, Mulvaney SA. Sharing and helping: predictors of adolescents' willingness to share diabetes personal health information with peers. J Am Med Inform Assoc 2018 Feb 1;25(2):135-141 [FREE Full text] [doi: 10.1093/jamia/ocx051] [Medline: 28575462]

52. Ressler PK, Bradshaw YS, Gualtieri L, Chui KK. Communicating the experience of chronic pain and illness through blogging. J Med Internet Res 2012 Oct 23;14(5):e143 [FREE Full text] [doi: 10.2196/jmir.2002] [Medline: 23092747]

53. Zhang J, Brackbill D, Yang S, Centola D. Efficacy and causal mechanism of an online social media intervention to increase physical activity: Results of a randomized controlled trial. Prev Med Rep 2015;2:651-657 [FREE Full text] [doi: 10.1016/j.pmedr.2015.08.005] [Medline: 26844132]

54. Litchman ML, Walker HR, Ng AH, Wawrzynski SE, Oser SM, Greenwood DA, et al. State of the science: a scoping review and gap analysis of diabetes online communities. J Diabetes Sci Technol 2019 May;13(3):466-492. [doi:

10.1177/1932296819831042] [Medline: 30854884]

55. Kingod N, Cleal B, Wahlberg A, Husted GR. Online peer-to-peer communities in the daily lives of people with chronic illness: a qualitative systematic review. Qual Health Res 2017 Jan;27(1):89-99. [doi: 10.1177/1049732316680203] [Medline: 27956659]

56. Litchman ML, Rothwell E, Edelman LS. The diabetes online community: older adults supporting self-care through peer health. Patient Educ Couns 2018 Mar;101(3):518-523. [doi: 10.1016/j.pec.2017.08.023] [Medline: 28947360]

57. Bissonnette-Maheux V, Provencher V, Lapointe A, Dugrenier M, Dumas A, Pluye P, et al. Exploring women's beliefs and perceptions about healthy eating blogs: a qualitative study. J Med Internet Res 2015 Apr 8;17(4):e87 [FREE Full text] [doi: 10.2196/jmir.3504] [Medline: 25858777]

58. Malik FS, Panlasigui N, Gritton J, Gill H, Yi-Frazier JP, Moreno MA. Adolescent perspectives on the use of social media to support type 1 diabetes management: focus group study. J Med Internet Res 2019 May 30;21(6):e12149 [FREE Full text] [doi: 10.2196/12149] [Medline: $\underline{31199310]}$

59. Litchman ML, Snider C, Edelman LS, Wawrzynski SE, Gee PM. Diabetes online community user perceptions of successful aging with diabetes: analysis of a \#DSMA Tweet Chat. JMIR Aging 2018 Jun 22;1(1):e10176 [FREE Full text] [doi: 10.2196/10176] [Medline: 31518231]

60. Gavrila V, Garrity A, Hirschfeld E, Edwards B, Lee JM. Peer support through a diabetes social media community. J Diabetes Sci Technol 2019 May;13(3):493-497 [FREE Full text] [doi: 10.1177/1932296818818828] [Medline: $\underline{\text { 30600704] }}$

61. Allen C, Vassilev I, Kennedy A, Rogers A. Long-term condition self-management support in online communities: a meta-synthesis of qualitative papers. J Med Internet Res 2016 Mar 10;18(3):e61 [FREE Full text] [doi: 10.2196/jmir.5260] [Medline: 26965990]

62. Cotter AP, Durant N, Agne AA, Cherrington AL. Internet interventions to support lifestyle modification for diabetes management: a systematic review of the evidence. J Diabetes Complications 2014;28(2):243-251 [FREE Full text] [doi: 10.1016/j.jdiacomp.2013.07.003] [Medline: 24332469]

63. Nordqvist C, Hanberger L, Timpka T, Nordfeldt S. Health professionals' attitudes towards using a web 2.0 portal for child and adolescent diabetes care: qualitative study. J Med Internet Res 2009 Apr 6;11(2):e12 [FREE Full text] [doi: 10.2196/jmir.1152] [Medline: 19403464]

64. Association of Diabetes Care \& Education Specialists. The Importance of Peer Support: Online and In-Person Support for People Living with Diabetes URL: https://www.diabeteseducator.org/living-with-diabetes/Tools-and-Resources/peer-support [accessed 2003-05-19]

65. Kovic I, Lulic I, Brumini G. Examining the medical blogosphere: an online survey of medical bloggers. J Med Internet Res 2008 Sep 23;10(3):e28 [FREE Full text] [doi: 10.2196/jmir.1118] [Medline: 18812312]

66. Litchman ML, Edelman LS. Perceptions of the Diabetes Online Community's Credibility, Social Capital, and Help and Harm: Cross-Sectional Comparison Between Baby Boomers and Younger Adults. JMIR Aging 2019 Sep 26;2(2):e10857 [FREE Full text] [doi: 10.2196/10857] [Medline: 31573907]

67. Ho Y, O'Connor BH, Mulvaney SA. Features of online health communities for adolescents with type 1 diabetes. West $\mathbf{J}$ Nurs Res 2014 Oct;36(9):1183-1198 [FREE Full text] [doi: 10.1177/0193945913520414] [Medline: 24473058] 
68. Keogh CJ, McHugh SM, Moloney MC, Hannigan A, Healy DA, Burke PE, et al. Assessing the quality of online information for patients with carotid disease. Int J Surg 2014;12(3):205-208 [FREE Full text] [doi: 10.1016/j.ijsu.2013.12.011] [Medline: 24380751]

69. Sharma N, Tridimas A, Fitzsimmons PR. A readability assessment of online stroke information. J Stroke Cerebrovasc Dis 2014 Jul;23(6):1362-1367. [doi: 10.1016/j.jstrokecerebrovasdis.2013.11.017] [Medline: 24389374]

\author{
Abbreviations \\ CVD: cardiovascular disease \\ CGM: continuous glucose monitor \\ DOC: diabetes online community \\ DQOLY: Diabetes Quality of Life for Youth \\ HbA $_{1 \mathbf{c}}$ : glycated hemoglobin \\ PAM: Patient Activation Measure \\ RCT: randomized controlled trial \\ T1D: type 1 diabetes
}

Edited by G Eysenbach; submitted 29.03.19; peer-reviewed by M Litchman, E Da Silva; comments to author 13.08.19; revised version
received 08.01.20; accepted 26.01.20; published 24.04.20
Please cite as:
Elnaggar A, Ta Park V, Lee SJ, Bender M, Siegmund LA, Park LG
Patients' Use of Social Media for Diabetes Self-Care: Systematic Review
J Med Internet Res 2020;22(4):e14209
URL: $\underline{\text { http://www.jmir.org/2020/4/e14209/ }}$
doi: $\underline{10.2196 / 14209}$
PMID: $\underline{32329745}$

(C)Abdelaziz Elnaggar, Van Ta Park, Sei J Lee, Melinda Bender, Lee Anne Siegmund, Linda G Park. Originally published in the Journal of Medical Internet Research (http://www.jmir.org), 24.04.2020. This is an open-access article distributed under the terms of the Creative Commons Attribution License (https://creativecommons.org/licenses/by/4.0/), which permits unrestricted use, distribution, and reproduction in any medium, provided the original work, first published in the Journal of Medical Internet Research, is properly cited. The complete bibliographic information, a link to the original publication on http://www.jmir.org/, as well as this copyright and license information must be included. 